\title{
MODELING SOIL PH FATE IN CRUDE OIL CONTAMINATED SOIL IN THE NIGER DELTA
}

\author{
N. L Nwakwasi ${ }^{1}$, J. C Osuagwu ${ }^{1}$, B. U Dike ${ }^{1}$, H. U. Nwoke \& J. C. Agunwamba ${ }^{2}$ \\ ${ }^{1}$ Department of Civil Engineering, Federal University of Technology Owerri, P. M. B 1526, Owerri, Nigeria \\ ${ }^{2}$ Department of Civil Engineering, University of Nigeria Nsukka \\ DOI: $10.31364 / S C I R J / v 6.111 .2018 . P 1118583$ \\ http://dx.doi.org/10.31364/SCIRJ/v6.i11.2018.P1118583
}

\begin{abstract}
Environmental degradation issues are of topical concern to communities in the Niger Delta region of Nigeria. Over the years, there has been strong agitation over polluted farm lands in the Niger Delta region by oil companies operating in the area. This is as a result of oil exploration and exploitation in the region. The people in the region can no longer expect good harvest from their farm lands due to oil pollution. This paper is set to investigate the effect of crude oil pollution on soil $\mathrm{pH}$ with time. The soil sample collected from the university research farm was artificially polluted with $0.05,0.1,0.15,0.2$, and 0.25 liters per $\mathrm{kg}$ of soil. The polluted soils were tested using standard methods at 14days interval. The panel Data Regression model (PDRM) was used to analyze the data. The result reveals that the soil pH content of the soil at various level of crude oil pollution varied with time. This can be attributed to mineralization and immobilization processes in the polluted soil environment. Over time, the soil $\mathrm{pH}$ content of the control sample was two (2) times lower than the values of soil $\mathrm{pH}$ content at various level of crude oil pollution. The high soil $\mathrm{pH}$ at various crude oil pollution level could also be due to reduced microbial activity and depressed soil pH mineralization occasioned by the alkalinity of the soil as a result of the carbonaceous substance in the crude oil. A model which can be used as a predictive tool to determine the level of soil $\mathrm{pH}$ fate in crude oil polluted soil has been developed.
\end{abstract}

Keywords: Crude oil, Pollution, soil pH, model, fluctuation.

\subsection{Introduction}

Globally there is a growing concern over environmental pollution and it's management. The three major areas of environmental pollution include water, air and land. One of the major causes of this environment pollution in Nigeria especially the Niger Delta region is as a result of hydrocarbon exploration and exploitation (Okwuosha, 2000). This has led to the degradation of farm lands, pollution of air, surface and ground waters due to gas flaring. The natural recovery of crude oil polluted land is slow. Communities affected are denied meaningful and economic use of their lands a long time. Hence modeling soil $\mathrm{pH}$ fate over time as a result of oil pollution has become imperative. The prediction will help to determine the level of degradation and possible bioremediation work to be carried out. A model may help to explain a system and to study the effect of different component and to make predictions about behavior. Modeling is a process of generating abstract, conceptual, graphical and or mathematical model. (Nwaogazie, 2006) defined modeling as the act of constructing or fashioning a model of something or finding a relationship between variables. The trend in modeling is to collect existing records (data), establish relations through mathematical equations, calibrate such equations in the way of assigning values of associated constant and adopting such equations for forecasting or prediction. Prediction takes us into the future for decision making as we examine different responses arising from changes in control variables. The panel data multiple regression analysis was chosen after considering some other engineering tools like finite element method, finite differences, neural network and Matlab due to its capacity to analyze data with several variables. It also gives the researcher a large number of data points by increasing the degree of freedom and reducing the collinearity among explanatory variables hence improving the capacity to produce the expected results in this research work. Analysis of the linear regression can be extended to cover situations in which the dependent variable is affected by several controlled variables (independent variables). In this case, the question is how soil $\mathrm{pH}$ is affected by crude oil pollution at various levels in the soil during the duration of pollution.

Given $n$ sets of measurements,

$\left(Y_{1}, X_{11}, X_{21}, X_{31}\right)----\left(Y_{n}, Y_{1 n}, X_{2 n}, X_{3 n}\right)$, the multiple regression equation is of the form

$Y=B_{0}+B_{1} X_{1}+B_{2} X_{2}+B_{3} X_{3} \ldots+B_{n} X_{n}$

The least square estimates for $\mathrm{B}_{0}, \mathrm{~B}_{1}$ and $\mathrm{B}_{3}$ can be obtained using Panel Data Computer Software. 
The fate of soil $\mathrm{pH}$ over time as a result of oil pollution is now a growing concern in the Niger Delta region of Nigeria. The objective of the study is to carry out a laboratory investigation using crude oil and soil samples collected from the region to determine the effect of crude oil pollution on the soil $\mathrm{pH}$ over a period of time. Other authours whose publications were reviewed in respect to this research work include: Abii, et al., (2009), Akinrede, et al., (2000), Akpan, (2014), Dobermann, et al, (2002), Johnson et al., (2001), Jones, (2001), Krishnakumar, et al.,(2000) and Lewbel, (1979).

1.1 Study Area

The study area is located in Owerri, Imo State and lies between latitude $5^{0} 22^{\prime} 51.5^{\prime \prime} \mathrm{N}$ and longitude $6^{0} 59^{\prime} 39^{\prime} 3^{\prime \prime} \mathrm{E}$, with an elevation of $61 \mathrm{~m}$. It is a humid tropical environment with average annual rainfall of $2400 \mathrm{~mm}$. The mean daily temperature is about $27^{\circ} \mathrm{C}$. The geological formation in the area shows that the soils are derived from coastal plain sands called acid sands - Benin formation (Orajaka, 1975).

\subsection{Methods}

The study was carried out over a period of sixteen (16) weeks using different containers measuring $17 \mathrm{~cm}$ (height) by $18.5 \mathrm{~cm}$ (diameter). Samples measuring 10kg polluted soil were placed in each of the containers and exposed to the same atmospheric and environmental conditions.

Table 1: Layout of experimental design

\begin{tabular}{|l|c|c|c|c|c|c|}
\hline Polluted Soil Sample & A & B & C & D & E & F \\
\hline Vol. of crude oil in Liters/kg of soil & 0 & 0.05 & 0.10 & 0.15 & 0.2 & 0.25 \\
\hline Variable monitored for ABCDEF was: & \multicolumn{7}{|c|}{ Soil pH } \\
\hline
\end{tabular}

The soil used in the study was collected from the Federal University of Technology Owerri (FUTO) Research Farm from $15 \mathrm{~cm}$ to $20 \mathrm{~cm}$ depth with shovel. The soil was measured into containers and taken to the laboratory for treatment (greenhouse treatment).

The soil was air dried for two weeks and sieved through $2.0 \mathrm{~cm}$ sieve. The soil samples labled B, C, D, E, F, each weighing 10kg were polluted with 0.5, 1.0, 2.0, 2.5 liters of crude oil (Bony light) respectively, and thoroughly mixed on a polythene sheet and put in a labeled container.

Sample A was not polluted and was used as the control. To maintain the moisture content of the soil, 50cl of water was sprinkled on each polluted soil sample at two weeks intervals.

The polluted samples were allowed to stay 14 days before commencement of analysis. The representative samples from (A, B, C, D, E, F) containers were taken at two weeks intervals to the soil science laboratory of Department of Crop, Soil and Pest Management, School of Agriculture and Agricultural Technology, FUTO for analysis to determine the fate of soil $\mathrm{pH}$ nutrient with time at various levels of pollution with crude oil. The concentration remaining after 14, 28, 42, 56, 70, 84, 98 and 112 days intervals were obtained.

For determination of soil $\mathrm{pH}$ twenty (20) grams air dried soil sample was put into $50 \mathrm{ml}$ beaker and $20 \mathrm{ml}$ of distilled water was added. The lump of the soil was stirred to form a homogenous slurry. The pH meter (3020 model) probe was immersed in the sample and allowed to stabilize at $25^{\circ} \mathrm{C}$. The $\mathrm{pH}$ value was taken and recorded. This was repeated for various levels of crude oil pollutions for the soil samples.

The Panel Data Computer Software called Stata 13 version was used to obtain the regression coefficients $\mathrm{B}_{0}, \mathrm{~B}_{1}, \mathrm{~B}_{2}, \mathrm{~B}_{3}$ and $\mathrm{B}_{4}$ and the model equation for soil $\mathrm{pH}$ using the data obtained from the laboratory. The model equation for the soil $\mathrm{pH}$ is expressed as: 
$Y_{i t}=B_{0}+B_{1} C_{v i t}+B_{2} T_{i t}+B_{3} T_{i t}^{2}+B_{4} \sqrt{C_{v i t}}+U_{i t}$

Where,

$$
\begin{array}{ll}
\mathrm{Y}_{\mathrm{it}} & =\text { soil } \mathrm{pH} \\
\mathrm{B}_{0} \mathrm{~B}_{1}, \mathrm{~B}_{2}, \mathrm{~B}_{3} \text { and } \mathrm{B}_{4} \quad=\text { model coefficients } \\
\mathrm{T}_{\mathrm{it}} \quad=\text { Number of days } \\
\mathrm{C}_{\mathrm{vit}}=\text { Crude oil volume in litres } \\
\mathrm{U}_{\mathrm{it}} \quad=\text { Random error of the model } \\
\mathrm{i} & =\text { crude oil pollution levels }(0,0.5,1.0,1.5,2.0) \\
\mathrm{t} & =\text { contact time for pollution (days) }
\end{array}
$$

\begin{tabular}{|c|c|c|c|c|c|c|}
\hline \multirow[b]{2}{*}{ source } & \multirow[b]{2}{*}{ ss } & \multirow[b]{2}{*}{ df } & \multirow[b]{2}{*}{ Ms } & \multicolumn{3}{|c|}{$\begin{array}{c}\text { Number of Obs }=48 \\
F(4,43)=620.95\end{array}$} \\
\hline & & & & \multicolumn{3}{|c|}{ Prob $>F=0.0000$} \\
\hline Model & 9.393115 & 4 & 2.34828 & \multicolumn{3}{|c|}{ R- Squared $=0.9830$} \\
\hline Residual & 0.16261645 & 43.000 & 0.0037818 & \multicolumn{3}{|c|}{ Adj R-Squared $=0.9814$} \\
\hline Total & 9.55573099 & 47 & 0.2033134 & \multicolumn{3}{|c|}{ Root MSE $=0.615$} \\
\hline OM & Coef & Std Err & $t$ & $P>|t|$ & $95 \%$ Conf. & Interval \\
\hline Conc & -0.7080021 & 0.0352156 & -20.1 & 0 & -0.779021 & -0.6369832 \\
\hline time & -0.0062861 & 0.0012756 & -4.93 & 0 & -0.0088585 & -0.0037137 \\
\hline time ${ }^{2}$ & $2.86 \mathrm{E}-05$ & $9.88 \mathrm{E}-06$ & 2.89 & 0.006 & 8.67E-06 & 0.0000485 \\
\hline conc $^{1 / 2}$ & 1.857124 & 0.0574353 & 32.33 & 0 & 1.741294 & 1.972953 \\
\hline _cons & 6.355381 & 0.0401394 & 158.33 & 0 & 6.274432 & 6.43633 \\
\hline
\end{tabular}

3.0 Results and Discussions

Table 2: The Variation of soil $\mathrm{pH}$ values with time after pollution.

\begin{tabular}{|l|r|r|r|r|r|r|}
\hline $\begin{array}{l}\text { Time } \\
\text { (days) }\end{array}$ & 0 & 0.5 & 1 & 1.5 & 2 & 2.5 \\
\hline 14 & 6.230 & 7.300 & 7.350 & 7.420 & 7.470 & 7.490 \\
\hline 28 & 6.210 & 7.200 & 7.330 & 7.400 & 7.420 & 7.450 \\
\hline 42 & 6.180 & 7.200 & 7.250 & 7.300 & 7.350 & 7.360 \\
\hline 56 & 6.100 & 7.000 & 7.200 & 7.270 & 7.290 & 7.300 \\
\hline 70 & 6.060 & 6.960 & 7.160 & 7.230 & 7.240 & 7.250 \\
\hline 84 & 6.020 & 7.150 & 7.180 & 7.190 & 7.210 & 7.230 \\
\hline 98 & 5.980 & 7.130 & 7.150 & 7.160 & 7.180 & 7.200 \\
\hline 112 & 5.920 & 7.120 & 7.140 & 7.160 & 7.190 & 7.210 \\
\hline
\end{tabular}

Table 2 shows the soil $\mathrm{pH}$ remaining in the soil after any given time ( $\mathrm{t}=14$ to 112 days), for values of soil samples with crude oil pollution volume ranging from 0 to $2.5 \mathrm{~L}$ per $10 \mathrm{Kg}$ of soil.

Table 3: Regression Model Coefficient for the proposed model 
The $\mathrm{R}^{2}$ for the determination for the proposed model is 0.9830 with a root mean square error of 0.6150 as shown in table 3 . The root mean square error is small, hence the adopted model fits (Chang, 2015). The P value of 0.00 shows that there is a strong relationship between soil $\mathrm{pH}$ and concentration of crude oil spilled at any given time. The equation for prediction of soil $\mathrm{pH}$ fate in crude oil depleted soil is therefore $p H=6.310-0.7080 C_{v i t}-0.0063 T_{i t}+2.86 \mathrm{e} T_{i t}^{2}+1.857 \sqrt{C_{v i t}}+0.0387$

The model was checked and adjusted using another set of experimental data. The model validation is represented in fig 1 and table 3 respectively. The values indicate closeness of the predicted values with the observed values, thus confirming the validity of the model developed (Essington, 2005).

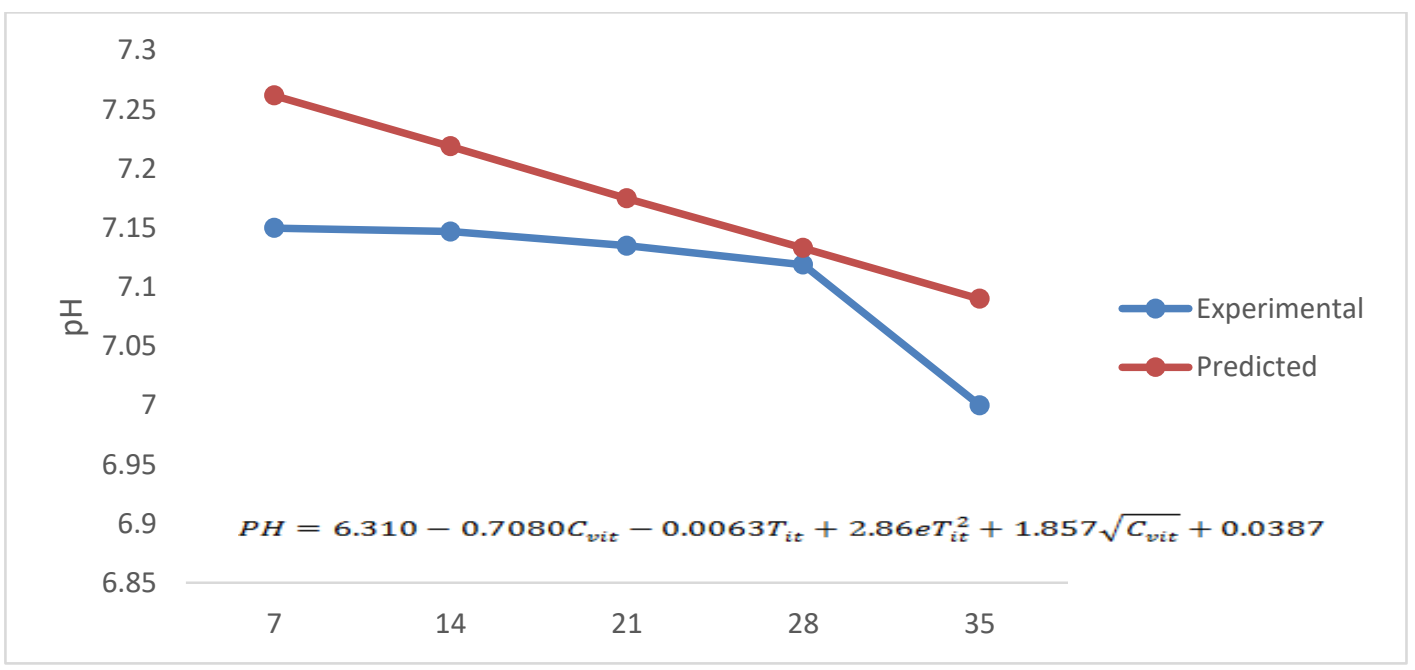

Fig 1: Experimental and predicted soil $\mathrm{pH}$ over time

Table 3: Experimental and Predicted Values for Soil pH over Time

\begin{tabular}{|l|l|l|l|}
\hline Time/Day & Experimental Data (ED) & Predicted Value (PV) & Percentage Difference \\
\hline 7 & 7.15 & 7.262 & \\
\hline 14 & 7.147 & 7.219 & 1.5 \\
\hline 21 & 7.135 & 7.175 & 1.0 (approx.) \\
\hline 28 & 7.119 & 7.133 & 0.5 \\
\hline 35 & 7 & 7.09 & 0.19 \\
\hline
\end{tabular}

Table 4 Experimental and Predicted Values of Soil pH at Various Pollution Levels Using Model Equation

\begin{tabular}{|c|c|c|c|c|}
\hline TIME & COV & ED for PH & PV for PH & \% Difference \\
\hline 14 & 0 & 6.230000019 & 6.272980213 & -0.689890754 \\
\hline 28 & 0 & 6.210000038 & 6.201789379 & 0.132216731 \\
\hline 42 & 0 & 6.179999828 & 6.141809464 & 0.617967086 \\
\hline 56 & 0 & 6.099999905 & 6.093039513 & 0.114104789 \\
\hline 70 & 0 & 6.059999943 & 6.055480003 & 0.07458646 \\
\hline 84 & 0 & 6.019999981 & 6.029130936 & -0.15167699 \\
\hline 98 & 0 & 5.980000019 & 6.013991833 & -0.568424976 \\
\hline 112 & 0 & 5.920000076 & 6.010063171 & -1.521336046 \\
\hline 14 & 0.5 & 7.300000191 & 7.232163906 & 0.929264149 \\
\hline 28 & 0.5 & 7.199999809 & 7.160973549 & 0.542031408 \\
\hline
\end{tabular}




\begin{tabular}{|c|c|c|c|c|}
\hline 42 & 0.5 & 7.199999809 & 7.100993156 & 1.375092437 \\
\hline 56 & 0.5 & 7 & 7.052223206 & -0.746045794 \\
\hline 70 & 0.5 & 6.960000038 & 7.014663696 & -0.785397383 \\
\hline 84 & 0.5 & 7.150000095 & 6.988314629 & 2.261335169 \\
\hline 98 & 0.5 & 7.130000114 & 6.973175526 & 2.199503314 \\
\hline 112 & 0.5 & 7.119999886 & 6.969247341 & 2.117311051 \\
\hline 14 & 1 & 7.349999905 & 7.422101974 & -0.980980555 \\
\hline 28 & 1 & 7.329999924 & 7.35091114 & -0.285282632 \\
\hline 42 & 1 & 7.25 & 7.290931225 & -0.564568618 \\
\hline 56 & 1 & 7.199999809 & 7.242161274 & -0.585575914 \\
\hline 70 & 1 & 7.159999847 & 7.204601765 & -0.622931819 \\
\hline 84 & 1 & 7.179999828 & 7.178252697 & 0.024333306 \\
\hline 98 & 1 & 7.150000095 & 7.163113594 & -0.183405574 \\
\hline 112 & 1 & 7.139999866 & 7.159184933 & -0.268698412 \\
\hline 14 & 1.5 & 7.420000076 & 7.485479832 & -0.882476479 \\
\hline 28 & 1.5 & 7.400000095 & 7.414289474 & -0.193099715 \\
\hline 42 & 1.5 & 7.300000191 & 7.354309082 & -0.743957396 \\
\hline 56 & 1.5 & 7.269999981 & 7.305539608 & -0.488853194 \\
\hline 70 & 1.5 & 7.230000019 & 7.267980099 & -0.525312304 \\
\hline 84 & 1.5 & 7.190000057 & 7.241630554 & -0.718087574 \\
\hline 98 & 1.5 & 7.159999847 & 7.226491928 & -0.928660365 \\
\hline 112 & 1.5 & 7.159999847 & 7.222563267 & -0.873790792 \\
\hline 14 & 2 & 7.46999979 & 7.483345509 & -0.178657547 \\
\hline 28 & 2 & 7.420000076 & 7.412155151 & 0.10572675 \\
\hline 42 & 2 & 7.349999905 & 7.352174759 & -0.029589855 \\
\hline 56 & 2 & 7.289999962 & 7.303404808 & -0.183879921 \\
\hline 70 & 2 & 7.239999771 & 7.265845299 & -0.356982437 \\
\hline 84 & 2 & 7.210000038 & 7.239496231 & -0.409101148 \\
\hline 98 & 2 & 7.179999828 & 7.224357605 & -0.617796347 \\
\hline 112 & 2 & 7.190000057 & 7.220428944 & -0.423211212 \\
\hline 14 & 2.5 & 7.489999771 & 7.43934536 & 0.676293897 \\
\hline 28 & 2.5 & 7.449999809 & 7.368155003 & 1.098588037 \\
\hline 42 & 2.5 & 7.360000134 & 7.30817461 & 0.70415112 \\
\hline 56 & 2.5 & 7.300000191 & 7.259405136 & 0.556096624 \\
\hline 70 & 2.5 & 7.25 & 7.221845627 & 0.388336182 \\
\hline 84 & 2.5 & 7.230000019 & 7.195496082 & 0.477232872 \\
\hline 98 & 2.5 & 7.199999809 & 7.180357456 & 0.272810466 \\
\hline 112 & 2.5 & 7.210000038 & 7.176428795 & 0.46562057 \\
\hline
\end{tabular}

Where

$\mathrm{COV}=$ Crude oil Volume

$\mathrm{ED}$ for $\mathrm{P}=$ Experimental Data for soil $\mathrm{pH}$

$\mathrm{PV}$ for $\mathrm{p}=$ Predicted value for soil $\mathrm{pH}$ 


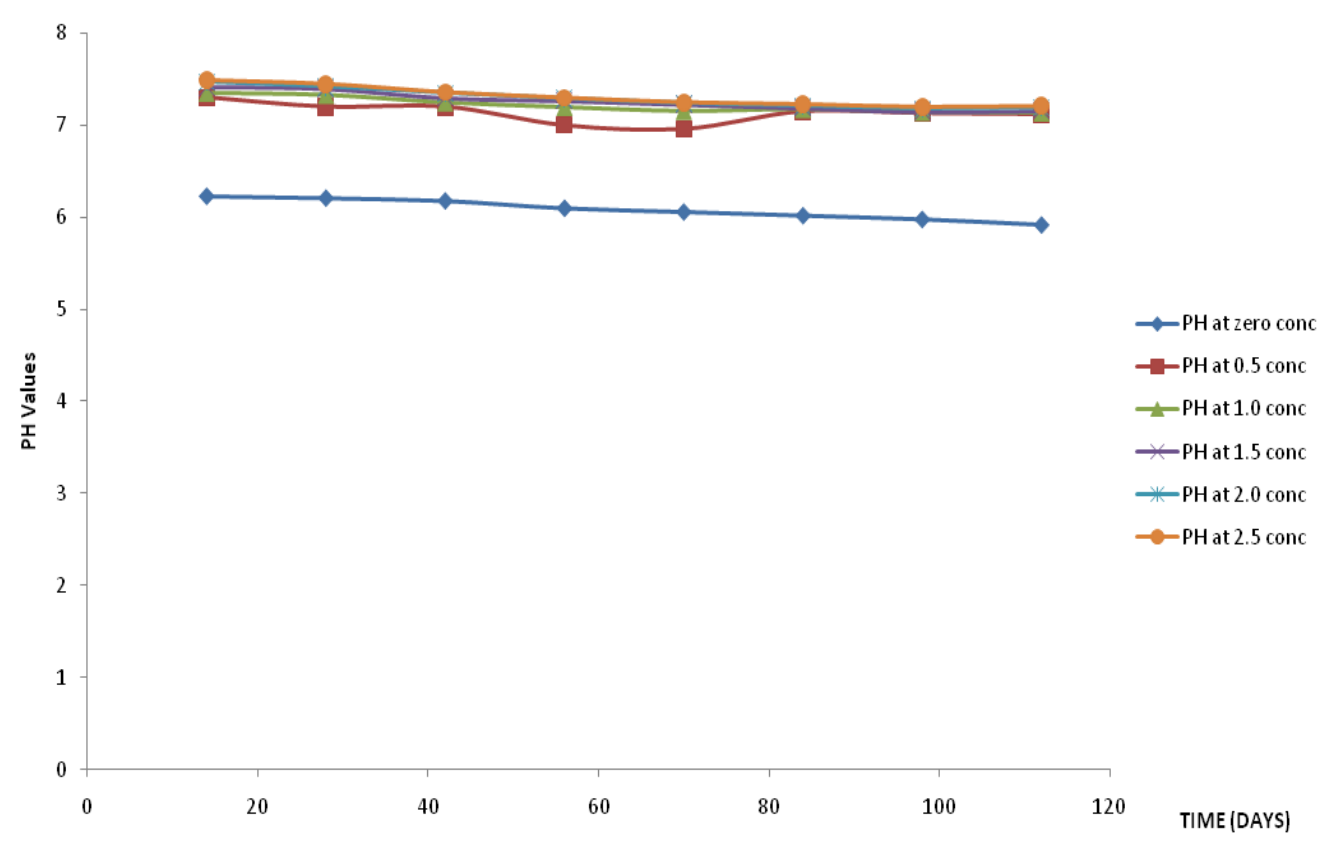

Fig 2: Soil $\mathrm{pH}$ at various crude oil levels with time

Figure 2 shows the graph of the control sample in comparism with the soil $\mathrm{pH}$ at various levels of crude oil pollution with time

The soil $\mathrm{pH}$ of the soil at various level of crude oil pollution varied with time of pollution as shown in Fig. 2 . The soil pH is not only essential for determining the availability of many soil nutrients, but also in determining the fate of many soil pollutants, their breakdown and possible movement through the soil. In other words $\mathrm{pH}$ measures the acidic and alkaline condition of soil and availability of micro and macronutrients to plants. The $\mathrm{pH}$ value increased slightly over a period of time being lowest at 56 days after pollution for 0.51 pollution level. The increase in $\mathrm{pH}$ value was attributed to the alkalinity of soil as a result of the carbonaceous substances in the crude oil.

\subsection{Conclusion}

The impact of crude oil pollution on the physcio-chemical properties of soil in relation to soil fertility in the Niger Delta Region of Nigeria has been reviewed. Modelling of soil pH fate in crude oil contaminated soil over a period of time was carried out. The soil pH value for various crude oil levels of pollution increased with time being lowest at 56days.

\section{References}

Abii, T.A. \& Nwosu, P.C. (2009). The Effect of oil Spillage on the soil of Eleme in Rivers State of the Niger-Delta Area of Nigeria. Research Journal Environmental Science, 3:316 - 320.

Akinrinde, E.A. \& Obigbesan, G.O. (2000). Evaluation of Fertility Status of Selected Soils for Crop Production in five Ecological Areas of Nigeria. Proc. 26th Annual Conf. Soil Sci. Soc. Nig. Ibadan, Oyo State. Pp. 279 - 288.

Akpan, I.E. (2014). Data requirements for modeling nutrient depletion in crude oil contaminated soil (Final year student project).

Dobermann, A.; Witt, C. \& Dawe, C. (2002). Site-specific Nutrient Management for Intensive Rice Cropping Systems in Asia. Field Crops Research 74(1), 24.

Enwezor, W.O., Ohiri, A.C., Opowaribo, E.E. \& E.J. Udo (1990). A review of soil fertilizer use in crops in Southern zone of Nigeria (in five volumes). Produced by the Fed. Min. of Agric. and National Research, Lagos.

Johnson, A.E.; Poulton, P.R. \& Syers, J.K. (2001). Phosphorus Potassium and Sulphur Cycles in Agricultural Soils. Proceedings No. 465. The International Fertilizer Society, York, UK, pp. $241-251$.

Jones, B. Jr (2001). Laboratory Guide for Conducting Soil Test and Plant Analysis, Wisconsin U.S.A, pp. 5 - 7. 
Krishnakumar, J. \& Ronchetti, E. (2000). Panel Data Econometrics: Future Directions, Papers in Honor of Professor Pietro Balestra. Amsterdam: North Holland, pp. 6 - 13.

Lewbel, A. (1979). "Efficient Estimation of Dynamic Error Components Models with Panel Data," Discussion Paper No. 79 - 118. Center for Economic Research, University of Minnesota.

Nwaogazie, L.L. (2006). Probability and Statistics for Science and Engineering Practice. University of Portharcourt press, Portharcourt Nigeria, pp. $1-12$.

Okwuosha S. C. (2000) Physico-chemical characterization of soil under the influence of gas flaring. A thesis submitted to the department of Crop and Soil Technology (pp 74 -88). Federal University of technology Owerri Imo State.

Orajaka, S. O. (1975). Geology in ofomata, GEK (ed), Nigeria in Maps: eastern states, Benin City ethiope publishing house. Pp 5-7 